\title{
Regulation of Hut Enzymes and Extracellular Protease Activities in Vibrio alginolyticus hut Mutants
}

\author{
By G. BOWDEN, M. A. MOTHIBELI, F. T. ROBB AND D. R. WOODS* \\ C.S.I.R. Applied Microbial Genetics Unit, Department of Microbiology, University of Cape Town, \\ Rondebosch 7700, South Africa
}

(Received 24 November 1981; revised 26 January 1982)

\begin{abstract}
The production of alkaline protease, collagenase and histidine utilization (Hut) enzymes by Vibrio alginolyticus wild-type, hutHl and hutUl strains was investigated. Alkaline protease synthesis was stimulated by histidine and urocanic acid in the wild-type and hutUl strains. In the hutHI mutant alkaline protease production was stimulated by urocanic acid and not by histidine. The Hut enzymes in the wild-type strain were coordinately induced by histidine. Urocanase and formimino-hydrolase were induced by histidine in the hutH1 mutant which lacked histidase and was not able to convert histidine to urocanic acid. Collagenase production in peptone medium was inhibited in the hut mutants. It is concluded that in $V$. alginolyticus urocanic acid regulates alkaline protease synthesis but that the Hut enzymes are induced by histidine. The involvement of the Hut genetic system in the regulation of alkaline protease and collagenase synthesis is discussed.
\end{abstract}

\section{INTRODUCTION}

Vibrio alginolyticus is an aerobic, halotolerant, Gram-negative bacterium which produces an extracellular collagenase and extracellular alkaline protease enzymes during the stationary growth phase (Welton \& Woods, 1973, 1975; Reid et al., 1978, 1980; Long et al., 1981). Common features in the control of collagenase and alkaline protease enzymes by $V$. alginolyticus include end-product and catabolite repression (Reid et al., 1978; Long et al., 1981) and specific regulation by temperature and oxygen (Hare et al., 1981). However, these two enzyme systems differ in that alkaline protease production does not require a specific inducer. Furthermore, alkaline protease production is stimulated by histidine and urocanic acid, whereas collagenase production is inhibited by these substances (Long et al., 1981).

The stimulation of alkaline protease production by histidine and urocanic acid suggests that the histidine utilization (Hut) pathway may be involved in the regulation of the alkaline proteases. In the Hut pathway histidine is converted to glutamic acid in four steps via the following intermediates: urocanic acid plus ammonia, 4-imidazolone-5-propionate and $N$-formimino-glutamate (Smith \& Magasanik, 1971). The enzymes involved are histidase, urocanase, amidohydrolase and formimino-hydrolase. In the Gram-negative bacteria Escherichia coli and Salmonella typhimurium, the Hut enzymes are induced by urocanic acid and histidine which is an inducer by virtue of its conversion to urocanic acid (Smith \& Magasanik, 1971; Smith et al., 1971; Hagen \& Magasanik, 1973). We have investigated the nature of the involvement of the Hut pathway in the control of alkaline protease production in $V$. alginolyticus by studying the regulation of the Hut enzymes.

\section{METHODS}

Bacterial strain, media and chemicals. The collagenolytic strain previously isolated and classified as Achromobacter iophagus by Welton \& Woods (1973) but recently reclassified as a V. alginolyticus strain was used (Reid et al., 1980). The bacterium was maintained on the complex medium of Welton \& Woods (1973). The peptone medium, 
minimal medium (MM) and succinate minimal medium (succinate MM) have been described previously (Reid et al., 1980; Long et al., 1981). The intermediates of the Hut pathway, L-histidine, urocanic acid, formimino-Lglutamic acid and L-glutamic acid were obtained from Sigma. For the characterization of the hut mutants the $\left(\mathrm{NH}_{4}\right)_{2} \mathrm{SO}_{4}$ in the MM was replaced by each of the intermediates $(0.25 \%$, w/v) of the Hut pathway to give the following media : histidine MM (his-MM), urocanic acid MM (uro-MM), formimino-L-glutamic acid MM (FGAMM) and the glutamic acid MM (glu-MM). The only nitrogen source in these different media was the Hut pathway intermediate.

Isolation of hut mutants. Hut mutants were obtained by treating exponential broth cultures with $100 \mu \mathrm{g} N$ Methyl- $N^{\prime}$-nitro- $N$-nitrosoguanidine $\mathrm{ml}^{-1}$ for $15 \mathrm{~min}$ at $30^{\circ} \mathrm{C}$ (Adelberg et al., 1965) in $0 \cdot 1 \mathrm{M}$-Tris/maleic acid buffer (pH 6.0) containing $0.4 \mathrm{M}-\mathrm{NaCl}, 0.4 \mathrm{mM}-\mathrm{MgSO}_{4}, 7.5 \mathrm{mM}-\left(\mathrm{NH}_{4}\right)_{2} \mathrm{SO}_{4}$ and $2 \mathrm{~mm}$-sodium acetate. The treated cultures were incubated in $\mathrm{MM}$ at $30^{\circ} \mathrm{C}$ for $24 \mathrm{~h}$ and the proportion of hut mutants was increased by resuspending washed cells in his-MM containing ampicillin $\left(20 \mu \mathrm{g} \mathrm{ml}^{-1}\right)$. The surviving cells were plated on to MM and the hut mutants identified by replica plating on to his-MM, uro-MM, FGA-MM and glu-MM plates.

Growth conditions for enzyme studies. The growth conditions for the production of collagenase and alkaline protease enzymes by stationary phase $V$. alginolyticus cells in succinate MM have been described previously (Reid et al., 1980; Long et al., 1981). The production of the Hut enzymes in stationary phase cells was investigated using the same growth conditions. Regulation of the Hut enzymes was also investigated in exponential MM cultures. The culture supernatants were assayed for collagenase or alkaline protease activities and the cells assayed for Hut enzymes.

Enzyme assays. All enzyme assays were performed at standardized cell densities. Each sample was assayed in duplicate and experiments were repeated at least three times. Collagenase was assayed using the synthetic collagenase substrate phenyl-azobenzyloxycarbonyl-L-propyl-L-leucyl-glycyl-L-propyl-D-arginine (Fluka, Buchs, Switzerland) as previously described (Wünsch \& Heidrich, 1963; Reid et al., 1978). Collagenase activity was expressed as nkat $\mathrm{ml}^{-1}$ where 1 kat is the amount of enzyme that converts 1 mol substrate $\mathrm{s}^{-1}$ (Florkin \& Stotz, 1973). Alkaline protease activities were assayed using the synthetic substrate azocasein (Sigma) (Long et al., 1981). One unit of alkaline protease activity is defined as the amount of enzyme that gives an increase in absorbance of $0 \cdot 1$ at $440 \mathrm{~nm}$ in $30 \mathrm{~min}$ at $40^{\circ} \mathrm{C}$.

Histidase, urocanase and formimino-hydrolase were assayed by the methods of Lund \& Magasanik (1965) and Chasin \& Magasanik (1968). Extracts $(50 \mu \mathrm{l})$ of toluenized cells $(0.5 \mathrm{ml}$ culture added to $0.5 \mathrm{ml}$ toluene) were assayed for histidase at $37^{\circ} \mathrm{C}$ as described by Chasin \& Magasanik (1968). Urocanase and formimino-hydrolase were assayed in sonicated extracts of cultures. Samples $(40 \mathrm{ml})$ of cultures were sedimented by centrifugation, washed with $40 \mathrm{ml} 0.05 \mathrm{M}$ cold $\left(4^{\circ} \mathrm{C}\right)$ potassium phosphate buffer $(\mathrm{pH} \mathrm{7.4)}$, resuspended in $2 \mathrm{ml}$ of the same buffer and sonicated for $2 \mathrm{~min}$ at $20 \mathrm{kHz}$ on ice. The resulting suspension was clarified by centrifugation in a microfuge (Beckman) at $11000 \mathrm{rev} . \mathrm{min}^{-1}$ for $1 \mathrm{~min}$. Samples $(0.1 \mathrm{ml})$ of the supernatants were assayed for urocanase as described by Chasin \& Magasanik (1968) and formimino-hydrolase by the method of Lund \& Magasanik (1965) as modified by Chasin \& Magasanik (1968). One unit of histidase or urocanase activity is defined as the amount of enzyme that gives an increase or decrease, respectively, in absorbance of 0.1 at $277 \mathrm{~nm}$ in $15 \mathrm{~min}$ at $37^{\circ} \mathrm{C}$. One unit of formimino-hydrolase activity is defined as the amount of enzyme that gives a decrease in absorbance of 0.1 at $485 \mathrm{~nm}$ in $30 \mathrm{~min}$ at $37^{\circ} \mathrm{C}$.

\section{RESULTS \\ Isolation of hut mutants}

Two groups of hut mutants were isolated. The first group were histidase mutants $($ hut $H)$ and were characterized by no growth on his-MM but they were able to grow on uro-MM, FGA-MM and glu-MM. The second group were urocanase mutants (hut $U$ ) which were unable to grow on uro-MM but grew on his-MM, FGA-MM and glu-MM. Growth on his-MM was sparse and was presumably due to the utilization of ammonia which was produced with urocanic acid from histidine by histidase (Smith \& Magasanik, 1971). A hutH mutant (hutH1) and a hutU mutant (hutUI) were chosen for further study. The Hut enzyme activities of these two mutants were determined and they were found to lack histidase and urocanase enzyme activities, respectively (Table 1).

\section{Effect of Hut intermediates on the induction of Hut enzymes}

The effect of intermediates in the Hut pathway on the production of histidase, urocanase and formimino-hydrolase by $V$. alginolyticus wild-type cells was investigated in stationary phase cultures (conditions for protease production) and in exponential phase cultures. In stationary 
Table 1. Production of histidase, urocanase and formimino-hydrolase enzymes by $V$. alginolyticus hut mutants

Stationary phase cultures were assayed for histidase, urocanase and formimino-hydrolase enzymes $4 \mathrm{~h}$ after resuspension in $\mathbf{M M}$ and his-MM at standardized cell densities.

\begin{tabular}{|c|c|c|c|c|}
\hline \multirow[b]{2}{*}{ Strain } & \multirow[b]{2}{*}{ Medium } & \multicolumn{3}{|c|}{ Enzyme activity (units $\mathrm{ml}^{-1}$ ) } \\
\hline & & Histidase & Urocanase & $\begin{array}{l}\text { Formimino- } \\
\text { hydrolase }\end{array}$ \\
\hline Wild-type & $\mathbf{M M}$ & 0.30 & $0 \cdot 20$ & 0.03 \\
\hline Wild-type & His-MM & $3 \cdot 23$ & $2 \cdot 57$ & 0.46 \\
\hline $\begin{array}{l}\text { HutHI } \\
\text { HutUI }\end{array}$ & $\begin{array}{l}\text { His-MM } \\
\text { His-MM }\end{array}$ & $\begin{array}{l}0 \cdot 10 \\
1.97\end{array}$ & $\begin{array}{l}2 \cdot 71 \\
0.12\end{array}$ & 0.40 \\
\hline nuter & HIS-MM & {$[\cdot 9]$} & 0.12 & 0.28 \\
\hline
\end{tabular}

Table 2. Hut mutants and the production of protease and Hut enzymes

Protease and Hut enzyme activities were determined in stationary phase cultures $4 \mathrm{~h}$ after resuspension at standardized cell densities in MM, his-MM and uro-MM. Protease activities were expressed as a percentage of the wild-type activity in MM and Hut enzyme activities as a percentage of wild-type activity in his-MM.

\begin{tabular}{|c|c|c|c|c|c|c|c|c|c|}
\hline \multirow[b]{2}{*}{ Strain } & \multicolumn{3}{|c|}{ Protease activity $(\%)$} & \multicolumn{2}{|c|}{ Histidase activity $(\%)$} & \multicolumn{2}{|c|}{ Urocanase activity $(\%)$} & \multicolumn{2}{|c|}{$\begin{array}{c}\text { Formimino-hydrolase } \\
\text { activity }(\%)\end{array}$} \\
\hline & MM & His-MM & Uro-MM & His-MM & Uro-MM & His-MM & Uro-MM & His-MM & Uro-MM \\
\hline Wild-type & 100 & 165 & 148 & 100 & 3 & 100 & 8 & 100 & 15 \\
\hline HutHl & 4 & 7 & 100 & 3 & 4 & 105 & 7 & 87 & 13 \\
\hline HutUI & 13 & 170 & 148 & 61 & 3 & 5 & 8 & 61 & 11 \\
\hline
\end{tabular}

phase cells the Hut enzymes were coordinately induced by histidine only. Urocanic acid and formimino-L-glutamic acid did not induce the Hut enzymes. Levels of activity of histidase, urocanase and formimino-hydrolase in the presence of histidine were $0.99,0.74$ and 0.67 units $\mathrm{ml}^{-1} \mathrm{~h}^{-1}$, respectively, measured over $4 \mathrm{~h}$. In uninduced control cultures in the absence of histidine or in the presence of either urocanic acid or formimino-L-glutamic acid, the levels of activity for histidase, urocanase and formimino-hydrolase varied between $0 \cdot 07-0 \cdot 22,0 \cdot 14-0 \cdot 18$ and $0.08-0.28$ units $\mathrm{ml}^{-1} \mathrm{~h}^{-1}$, respectively, measured over $4 \mathrm{~h}$. Similar results were obtained with exponential phase cultures.

\section{Hut mutants and the production of alkaline protease and Hut enzymes}

The production of alkaline protease and Hut enzymes by stationary phase $V$. alginolyticus wild-type, hutHl and hutUl strains was determined in MM, his-MM and uro-MM (Table 2). The alkaline protease activities of the wild-type strain were stimulated by histidine and urocanic acid. This was in agreement with our previous results (Long et al., 1981). The hutHl mutant produced very low levels of alkaline protease activity in $\mathbf{M M}$ and his-MM but showed significant alkaline protease activities in uro-MM. Although the hutHI mutant lacked histidase activity, the urocanase and formimino-hydrolase enzymes were induced by histidine. The Hut enzymes were not induced by urocanic acid in the hut H1 mutant. The alkaline protease activities of the hutUl mutant were stimulated by histidine and urocanic acid and similar levels of activity as the wild-type strain under the same conditions were obtained. In the absence of histidine and urocanic acid the hutUI mutant produced low levels of protease activity. The hutUI mutant lacked urocanase activity and histidase and formimino-hydrolase enzymes were induced by histidine but not by urocanic acid.

\section{Hut mutants and collagenase production}

The production of collagenase by the $V$. alginolyticus wild-type strain and the hutHI and hutUl mutants was determined at the same cell densities $4 \mathrm{~h}$ after resuspension in peptone medium. The wild-type cells produced 3.84 nkat $\mathrm{ml}^{-1}$ of collagenase. The hutHI and hutUl 
mutants produced 0.65 and $0.54 \mathrm{nkat} \mathrm{ml}^{-1}$ of collagenase, respectively ( 17 and $14 \%$ of the wildtype collagenase activity, respectively).

\section{DISCUSSION}

The stimulation of alkaline protease synthesis by urocanic acid and analogy with the control of the Hut operon in E. coli and S. typhimurium (Smith \& Magasanik, 1971; Hagen \& Magasanik, 1973) suggested that urocanic acid is the inducer of alkaline protease synthesis. Histidine is an inducer by virtue of its conversion to urocanic acid. Studies with the hutH1 and hutUI mutants confirmed these suggestions since alkaline protease production in the hutHl mutant was stimulated by urocanic acid but not by histidine. As would be expected, alkaline protease activity in the hutU1 mutant was stimulated by both histidine and urocanic acid. However, a surprising discovery was that in the $V$.alginolyticus strain histidine (and not urocanic acid) is the inducer of the Hut enzymes. This can be concluded from the results of induction experiments with Hut intermediates and from the induction of urocanase and formimino-hydrolase by histidine in the hutHI mutant which cannot convert histidine to urocanic acid. The production of amidohydrolase which is the third enzyme in the Hut pathway, was not investigated because of the non-availability and instability of 4-imidazolone-5-propionate (Smith et al., 1971).

Although $V$. alginolyticus is a Gram-negative bacterium, regulation of the Hut pathway is not similar to that in E. coli and S. typhimurium (Smith \& Magasanik, 1971; Hagen \& Magasanik, 1973). However, it is similar to the Gram-positive bacterium Bacillus subtilis in that in both bacteria histidine is the inducer of the Hut enzymes (Chasin \& Magasanik, 1968). The $V$. alginolyticus strain and Bacillus strains are also similar in other respects: they produce true extracellular proteases during the stationary growth phase (Priest, 1977); protease production is rifampin-insensitive (Both et al., 1972; O'Connor et al., 1978; Reid et al., 1980) and it is subject to end-product repression and catabolite repression which is not relieved by cAMP (Glenn, 1976; Priest, 1977; Reid et al., 1978; Long et al., 1981).

The decreased constitutive level of alkaline protease synthesis in the hutU1 mutant in MM is interesting since elevated constitutive protease synthesis would normally have been expected. Urocanic acid would be expected to accumulate in the hutUl mutant since histidine made endogenously would give rise to urocanic acid which cannot be metabolized and would therefore induce alkaline protease synthesis. This suggests that the regulation of alkaline protease synthesis by the Hut operon is complex and does not only involve urocanic acid concentrations. Similarly, the involvement of the Hut operon in the regulation of collagenase synthesis is also suggested by the inhibition of collagenase synthesis in the hut mutants.

G. Bowden acknowledges a postgraduate research bursary from the South African Council for Scientific and Industrial Research.

\section{REFERENCES}

Adelberg, E. A., Mandel, M. \& Chen, G. C. C. (1965). Optimal conditions for mutagenesis by $\mathrm{N}$ methyl- $N^{\prime}$-nitro- $N$-nitrosoguanidine in Escherichia coli K12. Biochemical and Biophysical Research Communications 18, 788-795.

Both, G. W., McInnes, J. L., Hanlon, J. E., May, B. K. \& Elliott, W. H. (1972). Evidence for an accumulation of messenger RNA specific for extracellular protease and its relevance to the mechanism of enzyme secretion in bacteria. Journal of Molecular Biology 67, 199-217.

Chasin, L. A. \& Magasanik, B. (1968). Induction and repression of the histidine-degrading enzymes of $\mathrm{Ba}$ cillus subtilis. Journal of Biological Chemistry 243, 5165-5178.

Florkin, M. \& Stotz, E. M. (1973). Comprehensive Biochemistry, vol. 13, 3rd edn. Amsterdam: Elsevier.
GlenN, A. R. (1976). Production of extracellular proteins by bacteria. Annual Review of Microbiology 30, 41-62.

HAGEN, D. C. \& MAGaSANIK, B. (1973). Isolation of the self regulated repressor protein hut operons of Salmonella typhimurium. Proceedings of the National Academy of Sciences of the United States of America 70, 808-812.

Hare, P., Long, S., Robb, F. T. \& Woods, D. R. (1981). Regulation of exoprotease production by temperature and oxygen in Vibrio alginolyticus. Archives of Microbiology 130, 276-280.

Long, S., Mothibeli, M. A., Robb, F. T. \& Woods, D. R. (1981). Regulation of alkaline protease activity by histidine in a collagenolytic Vibrio alginolyticus strain. Journal of General Microbiology 127, 193199. 
Lund, P. \& MagasaniK, B. (1965). $N$-formimino-Lglutarate-formimino hydrolase of Aerobacter aerogenes. Journal of Biological Chemistry 240, 43164319.

O'Connor, R., Elliot, W. H. \& MaY, B. K. (1978). Modulation of an apparent mRNA pool for extracellular protease in Bacillus amyloliquefaciens. Journal of Bacteriology 136, 24-34.

PRIEST, F. G. (1977). Extracellular enzyme synthesis in the genus Bacillus. Bacteriological Reviews 41, 711 753.

ReID, G. C., RoBb, F. T. \& Woods, D. R. (1978). Regulation of extracellular collagenase production in Achromobacter iophagus. Journal of General Microbiology 109, 149-154.

ReID, G. C., Woods, D. R. \& RobB, F. T. (1980). Peptone induction and rifampicin insensitive collagenase production by Vibrio alginolyticus. Journal of Bacteriology 142, 447-454.
Smith, G. R. \& Magasanik, B. (1971). The two operons of the histidine utilisation system in Salmonella typhimurium. Journal of Biological Chemistry 246, 3330-3341.

Smith, G. R., Halpern, J. S. \& Magasanik, B. (1971). Genetic and metabolic control of enzymes responsible for histidine degradation in Salmonella typhimurium. Journal of Biological Chemistry 246, 33203329.

Welton, R. L. \& Woods, D. R. (1973). Halotolerant collagenolytic activity of Achromobacter iophagus. Journal of General Microbiology 75, 191-196.

Welton, R. L. \& Woods, D. R. (1975). Collagenase production by Achromobacter iophagus. Biochimica et biophysica acta 384, 228-234.

WüNSCH, E. \& HEIDRICH, H. G. (1963). Zur quantitativen bestimmung der kollagenase. Hoppe-Seyler's Zeitschrift für physiologische Chemie 333, 149-151. 